\title{
Plant Survival in the Arid Southwest \\ 30 Years after Seeding
}

\section{B. IRA JUDD AND LARRY W. JUDD}

Highlight: Adaptability and survival of range plantings are important to those interested in artificial seeding of rangelands. An analysis of exotic plantings made in 1945 in the semidesert shrub, chaparral, semidesert grassland, and pinyon-juniper in the Tonto National Forest, Arizona, show that, of 48 species planted, 13 appear to be able to survive for at least 20 years and should be candidates for restoring depleted rangelands and seven survived for a 30-year period. No species survived for the 30 years in the semidesert shrub and pinyon-juniper types. Boer and Lehmann lovegrasses, blue panicgrass, sand dropseed, and menodora survived in the chaparral and crested wheatgrass and weeping lovegrass in the grassland.

Revegetation of depleted rangelands was an early subject for research. Griffiths (1907) concluded that reseeding on an economic basis is applicable only to those areas where moisture is adequate. Sampson (1913) and Glendening (1937a, 1937b, 1938) stressed the importance of soil treatment, covering seed, and protecting seeded areas with mulch until plants are established. This paper reports results of survival of 41 species of grasses and grasslike plants, and 7 species of shrubs that were seeded in the arid Southwest 30 years ago.

\section{Sites, Plantings, and Results}

Four planting sites were located in four vegetation types (semidesert shrub, chaparral, semidesert grassland, and pinyon-juniper) on the Tonto $\mathrm{Na}$ tional Forest in Arizona. These types were selected because they constitute a major portion of the forest acreage and represent difficult management situations because of low rainfall.

\section{Semidesert Shrub}

This site is occupied principally by mesquite (Prosopis juliflora (Swartz) D.C.), catclaw acacia (A cacia greggii A. Gray), paloverde (Cerdidium spp.), and spiny hackberry (Celtis pallida Torr.). In the early spring there is usually a dense ground cover of woolly

Authors are professor emeritus, Arizona State University, Tempe, and industrial education instructor, Westwood High School, Mesa, Ariz.

The authors wish to express deep appreciation to Dr. David R. Patton, wildlife biologist, Rocky Mountain Forest and Range Experiment Station, Tempe, for reviewing the manuscript and offering helpful suggestions.

Manuscript received April 7, 1975.
Indianwheat (Plantago purshi Roem. and Shult.) with some annual grasses. Elevation is approximately 2,100 feet. Annual precipitation varies from 8 to inches. This site represents an extreme environment to seed because of low temperatures, high temperatures and evaporation rates, and surface-sealing of soils.

In 1945 plantings were made in a semidesert shrub site using the following methods: (1) disking, broadcast seeding, cultipacking, and mulching with native brush; (2) disking, broad25 inches with an average of about 16 cast seeding, and cultipacking; (3) disking, broadcast seeding, and harrowing; (4) broadcast seeding and disking; (5) broadcast seeding and harrowing; and (6) broadcast seeding without site preparation. In 1946 half of the 1945 seedings were replanted and an additional 21 range species were planted in mulched rows. All plantings were made in June.

By September 1945 Boer and Lehmann lovegrasses ${ }^{1}$, bush muhly, and hooded windmillgrass had emerged in plots which were disked and cultipacked (Table 1). Plains bristlegrass and Rothrock grama had emerged in row plantings. In 1946 the only plants surviving were under the brush mulch. Several plots protected from grazing had approximately four times the plant density and double the plant height of those in grazed plots.

In 1947 the two lovegrasses main-

${ }^{1}$ Scientific names of plants seeded are given in Table 1.

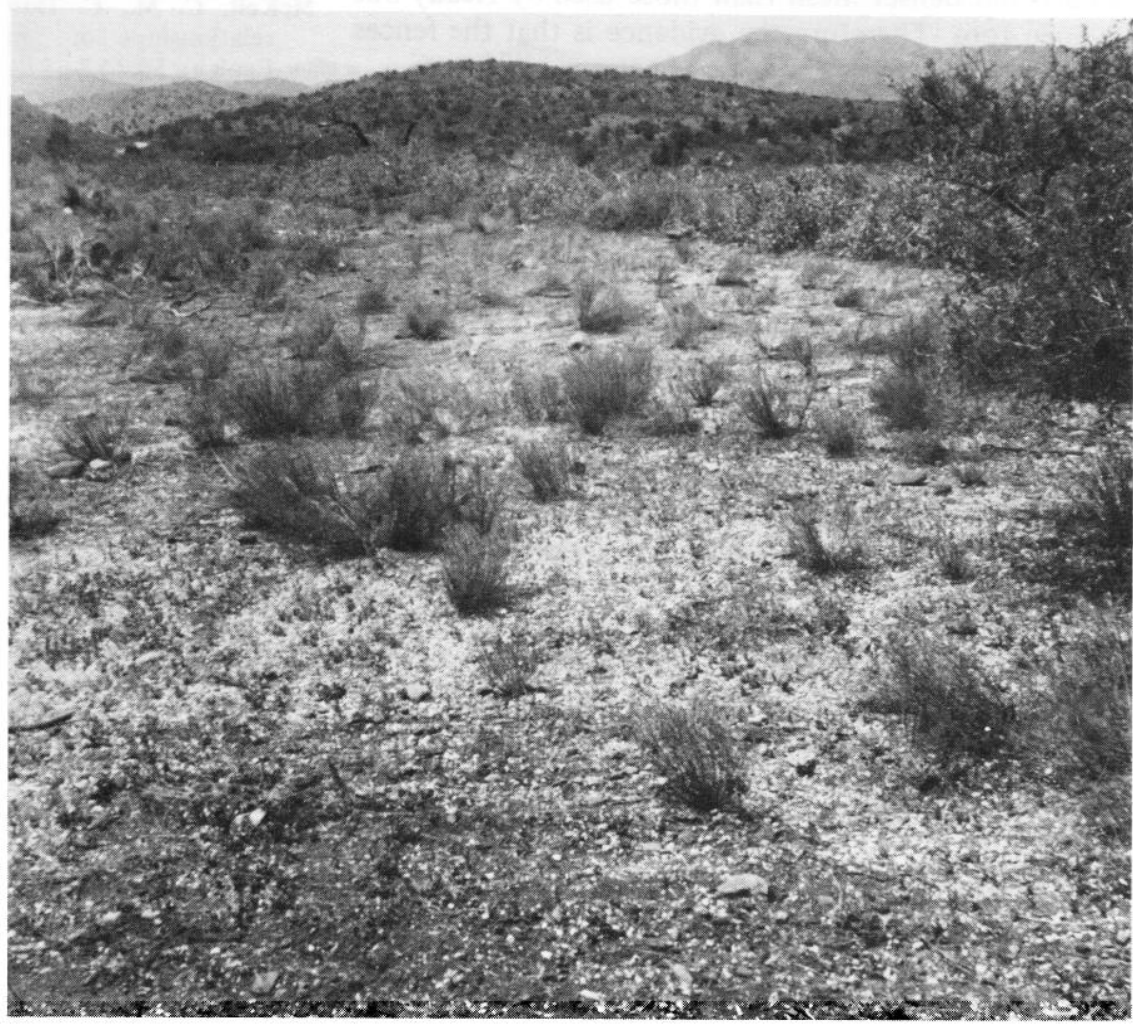

Fig. 1. Chaparral planting site, 1945. 
Table 1. Survival of species planted in four vegetation types.

\begin{tabular}{|c|c|c|c|c|c|c|c|c|c|c|c|c|c|}
\hline \multirow[b]{3}{*}{ Common name } & \multirow[b]{3}{*}{ Scientific namc } & \multirow{2}{*}{\multicolumn{4}{|c|}{$\begin{array}{l}\text { Sites }^{1} \text { planted } \\
\text { in } 1945 \\
\end{array}$}} & \multicolumn{8}{|c|}{ Species survival } \\
\hline & & & & & & \multicolumn{4}{|c|}{1965} & \multicolumn{4}{|c|}{1975} \\
\hline & & 1 & 2 & 3 & 4 & 1 & 2 & 3 & 4 & 1 & 2 & 3 & 4 \\
\hline \multicolumn{14}{|l|}{ Grasses and grasslike plants } \\
\hline Crested wheatgrass & Agropyron desertorium (Fisch.) Schult & & $\mathrm{x}$ & $\mathrm{x}$ & $\mathbf{x}$ & & & $\mathrm{x}$ & $\mathbf{x}$ & & & $\mathrm{x}$ & \\
\hline Intermediate wheatgrass & A. intermedium (Host) Beauv. & & & $\mathrm{x}$ & $\mathrm{x}$ & & & & & & & & \\
\hline Western wheatgrass & A. smithii $\mathrm{Rydb}$. & & $\mathrm{x}$ & $\mathbf{x}$ & $\mathrm{x}$ & & & & $x$ & & & & \\
\hline Pubescent wheatgrass & A. trichophorum (Link) Richt. & & & $\mathrm{x}$ & $\mathbf{x}$ & & & & & & & & \\
\hline Cane bluestem & Andropogon barbinodis Lag. & $\mathrm{x}$ & $\mathrm{x}$ & & & & & & & & & & \\
\hline Turkestan bluestem & A. ischaemum $\mathrm{L}$. & & & $\mathbf{x}$ & $\mathbf{x}$ & & & & $\mathbf{x}$ & & & & \\
\hline Little bluestem & A. scoparius Michx. & & & $\mathbf{x}$ & $\mathrm{x}$ & & & & $\mathbf{x}$ & & & & \\
\hline Curly mitchellgrass & Astrebla lappacea (Lind1.) Domin. & $\mathrm{x}$ & $\mathrm{x}$ & & & & & & & & & & \\
\hline Sideoats grama & Bouteloua curtipendula (Michx.) Torr. & & & $\mathbf{x}$ & $\mathrm{x}$ & & & & & & & & \\
\hline Black grama & B. eriopoda Torr. & & $\mathrm{x}$ & $\mathbf{x}$ & $\mathrm{x}$ & & & & & & & & \\
\hline Slender grama & B. filiformis (Fourn.) Griffiths & & $\mathrm{x}$ & & $\mathbf{x}$ & & $\mathbf{x}$ & & & & & & \\
\hline Blue grama & B. gracilis (H.B.K.) Lag. & & & $\mathrm{x}$ & $\mathrm{x}$ & & & & & & & & \\
\hline Hairy grama & B. hirsuta Lag. & & $\mathrm{x}$ & $\mathrm{x}$ & & & & & & & & & \\
\hline Rothrock grama & B. rothrockii Vasey & $\mathrm{x}$ & $\mathrm{x}$ & & & & & & & & & & \\
\hline Smooth brome & Bromus inermis Leyss. & & & $\mathrm{x}$ & $\mathrm{x}$ & & & & & & & & \\
\hline Indian sandbur & Cenchrus biflorus Roxb. & $\mathrm{x}$ & $\mathrm{x}$ & & & & & & & & & & \\
\hline Hooded windmillgrass & Chloris cuculata $\mathrm{B}$ isch. & $\mathrm{x}$ & $\mathrm{x}$ & & & & & & & & & & \\
\hline Uruguay chloris & C. berroi Arech. & $\mathrm{x}$ & $\mathrm{x}$ & & & & & & & & & & \\
\hline Bicolor lovegrass & Eragrostis bicolor Nees & $\mathrm{x}$ & $\mathrm{x}$ & & & & & & & & & & \\
\hline Boer lovegrass & E. chloromelas Steud. & $\mathrm{x}$ & $\mathrm{x}$ & & & $\mathbf{x}$ & $\mathrm{x}$ & & & & $\mathbf{x}$ & & \\
\hline \multirow[t]{2}{*}{ Weeping lovegrass } & E. curvula (Schrad.) Nees & $\mathbf{x}$ & $\mathrm{x}$ & $\mathrm{x}$ & $\mathbf{x}$ & & & $\mathbf{x}$ & $\mathbf{x}$ & & & $\mathbf{x}$ & \\
\hline & E. echinochloidea Stapf. & $\mathrm{x}$ & $\mathrm{x}$ & & & & & & & & & & \\
\hline Plains lovegrass & E. intermedia Hitchc. & & & $\mathrm{x}$ & $\mathrm{x}$ & & & & & & & & \\
\hline Lehmann lovegrass & E. lehmanniana Nees & $\mathrm{x}$ & $\mathrm{x}$ & $\mathrm{x}$ & & $\mathbf{x}$ & $\mathrm{x}$ & & & & $\mathrm{x}$ & & \\
\hline Wilman lovegrass & E. superba Peyr. & $\mathrm{x}$ & & & & & & & & & & & \\
\hline Sand lovegrass & E. trichodes (Nutt.) Wood & & & $\mathrm{x}$ & $\mathrm{x}$ & & & & & & & & \\
\hline Tanglehead & Heteropogon contortus (L.) Beauv. & & & $\mathrm{x}$ & $\mathrm{x}$ & & & & & & & & \\
\hline Curlymesquite & Hilaria belangeri (Steud.) Nash & & $\mathrm{x}$ & & & & & & & & & & \\
\hline Wolftail & Lycurus phleoides H.B.K. & & & $\mathbf{x}$ & $\mathbf{x}$ & & & & & & & & \\
\hline Bush muhly & Muhlenbergia porteri Scribn. & $\mathbf{x}$ & & & & $\mathrm{x}$ & & & & & & & \\
\hline Deergrass & M. rigens (Benth.) Hitchc. & & & $\mathbf{x}$ & $\mathbf{x}$ & & & & & & & & \\
\hline Smilograss & Oryzopsis miliacea (L.) Benth. and Hook & & & $\mathbf{x}$ & $\mathrm{x}$ & & & & & & & & \\
\hline Blue panicgrass & Panicum antidotale Retz. & & $\mathrm{x}$ & & & & $\mathrm{x}$ & & & & $\mathrm{x}$ & & \\
\hline Vinemesquite & P. obtusum H.B.K. & & & $\mathrm{x}$ & $\mathrm{x}$ & & & & & & & & \\
\hline Sand paspalum & Paspalum stramineum Nash & $\mathrm{x}$ & $\mathrm{x}$ & & & & & & & & & & \\
\hline Buffelgrass & Pennisetum ciliare (L.) Link & $\mathrm{x}$ & $\mathrm{x}$ & & & & & & & & & & \\
\hline Plains bristlegrass & Setaria macrostachya H.B.K. & $\mathbf{x}$ & & & & & & & & & & & \\
\hline Sand dropseed & Sporobolus cryptandrus (Torr.) A. Gray & $\mathrm{x}$ & $\mathrm{x}$ & & & & $\mathrm{x}$ & & & & $\mathbf{x}$ & & \\
\hline White tridens & Tridens albescens (Vasey) Woot. and Standl. & & $\mathrm{x}$ & $\mathrm{x}$ & $\mathrm{x}$ & & $\mathrm{x}$ & $\mathrm{x}$ & & & & & \\
\hline Rough tridens & T. elongatus (Buckl.) Nash & & $\mathrm{x}$ & & $\mathrm{x}$ & & & & & & & & \\
\hline Slim tridens & T. muticus (Torr.) Nash & $\mathrm{x}$ & $\mathrm{x}$ & $\mathrm{x}$ & & & & & & & & & \\
\hline Arizona cottontop & Trichachne californica (Benth.) Chase & $\mathrm{x}$ & & & & & & & & & & & \\
\hline \multicolumn{14}{|l|}{ Shrubs } \\
\hline Fourwing saltbush & Atriplex canescens (Pursh) Nutt. & $\mathrm{x}$ & $\mathrm{x}$ & $\mathrm{x}$ & $\mathrm{x}$ & & & & & & & & \\
\hline Spiny saltbush & A. confertifolia (Torr. and Frem.) S. Wats. & $\mathrm{x}$ & $\mathbf{x}$ & & & & & & & & & & \\
\hline Showy menodora & Menodora longiflora A. Gray & $\mathrm{x}$ & $\mathbf{x}$ & & & & & & & & & & \\
\hline Rough menodora & M. scabra A. Gray & $\mathbf{x}$ & $\mathrm{x}$ & & & & $\mathbf{x}$ & & & & $\mathrm{x}$ & & \\
\hline Broom menodora & M. scoparia Engelm. & $\mathrm{x}$ & $\mathrm{x}$ & & & & & & & & & & \\
\hline Australian sheepbush & Pentzia incana (Thumb.) O. Kunfze & $\mathbf{x}$ & $\mathbf{x}$ & & & & & & & & & & \\
\hline Antelope bitterbrush & Purshia tridentata (Pursh) D C. & & & $\mathrm{x}$ & $\mathrm{x}$ & & & & & & & & \\
\hline
\end{tabular}

${ }^{1}$ Sites planted were: 1 = semidesert shrub; 2 = chaparral; 3 = semidesert grassland; and 4 = pinyon-juniper.

tained good stands while bush muhly and hooded windmillgrass had poor stands. Lehmann lovegrass, and plains bristlegrass were surviving in the row plantings. By 1949 survival was confined mostly to mulched plots and to Lehmann lovegrass, Boer lovegrass, bush muhly, and hooded windmillgrass. Hooded windmillgrass and plains bristlegrass did not survive after 1954. The two lovegrasses and bush muhly survived until sometime between 1962 and 1965.

Chaparral

This site is about 50 miles north of
Phoenix, Ariz. It is covered principally with scrub liveoak (Quercus turbinella Greene) and broom snakeweed (Gutierrezia sarothrae (Pursh) Britt. and Rusby), with a scattering of Utah juniper (Juniperus osteosperma (Torr.) Little), pricklypear (Opuntia spp.), and curlymesquite (Hilaria belangeri (Steud.) Nash). The elevation is near 3,500 feet. Average annual precipitation is about 18 inches.

The area was so rocky that plots were first seeded and then harrowed. Harrowing destroyed from 5 to $10 \%$ of the broom snakeweed but little dam- age occurred to other shrubs. All the seeding was completed in August. By 1949, under juniper slash, there were good stands of Boer and Lehmann lovegrass and white tridens. Since that time there have appeared, intermittently, plants of blue panicgrass, crested wheatgrass, and slender grama. By 1965 the surviving species were Boer lovegrass with only scattered plants of sand dropseed, blue panicgrass, Lehmann lovegrass, white tridens, and rough menodora. All of these species, except white tridens, were surviving in 1975. 


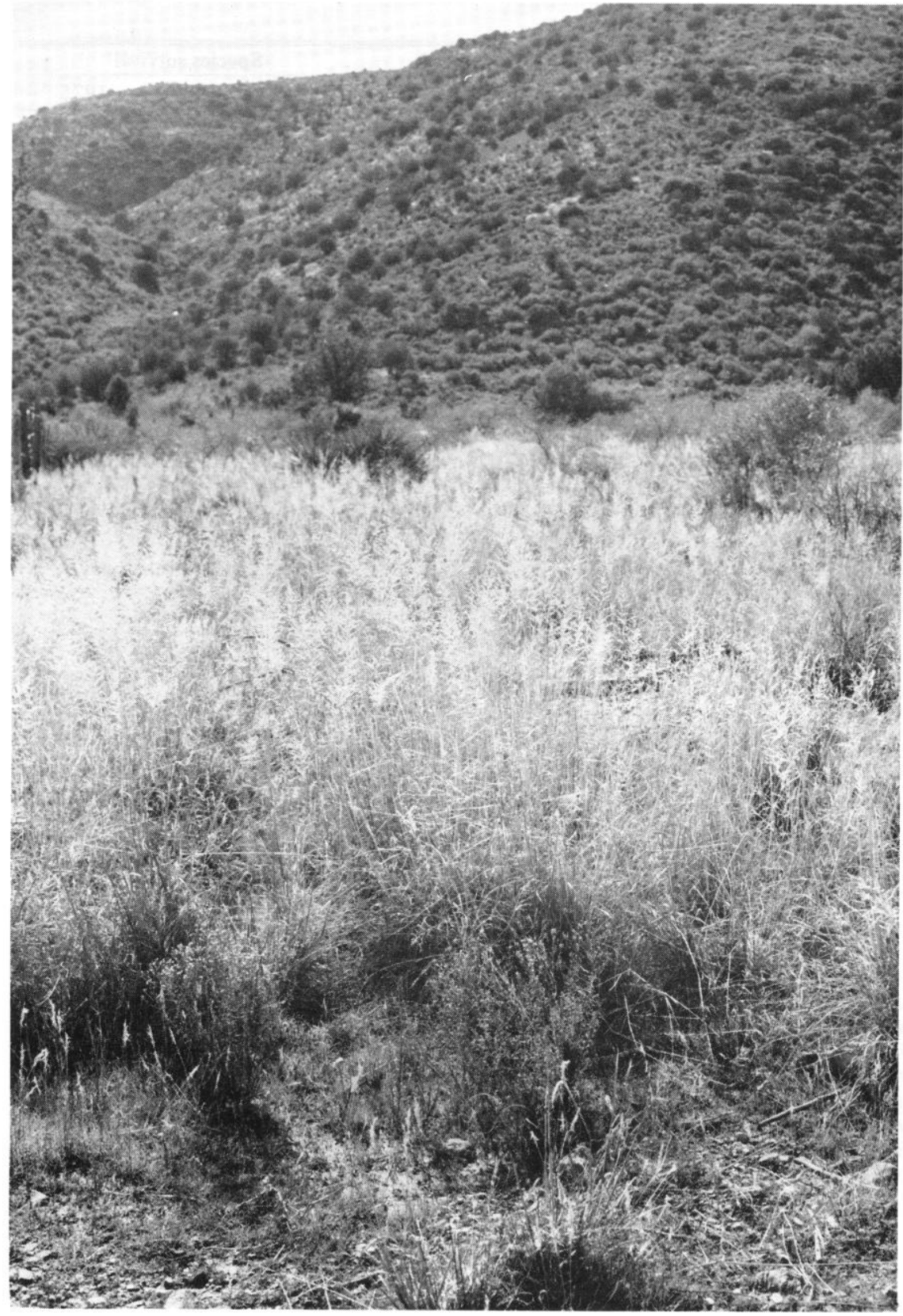

Fig. 2. Chaparral planting site, 1975.

\section{Semidesert Grassland}

This site is a formerly cultivated and severely eroded area approximately 10 miles north of Young, Ariz. There were existing patches of sod of western wheatgrass, blue grama, and sideoats grama. The approximate elevation is 5,100 feet. Annual precipitation is 21 inches. Treatments were: (1) disking, broadcast seeding, and mulching; (2) disking, broadcast seeding, and cultipacking; and (3) broadcast seeding without seedbed preparation.

There was no plant emergence by the fall of 1945. By 1946 there were fair stands of Lehmann lovegrass, weeping lovegrass surviving. Those plots reseeded to western wheatgrass maintained a heavier stand than those seeded naturally. All plantings made without seedbed preparation failed. Crested wheatgrass and weeping lovegrass were still surviving in 1975 .

\section{Pinyon-juniper}

This site is located 5 miles southeast of Pine, Arizona. It has a rather dense overstory of juniper and a thick ground cover of broom snakeweed. There was a remnant of sod composed principally of sideoats grama and blue grama. The elevation is approximately 5,000 feet. The average annual precipitation is 21 inches.

One planting area at the site had four treatments: (1) disking, broadcast seeding, and cultipacking; (2) disking, broadcast seeding, cultipacking, and mulching with native brush; and (3) broadcast fertilizing, disking, and broadcast seeding. A second area had: (1) juniper removal, disking, broadcast seeding, and mulching; (2) juniper removal, and broadcast seeding; and (3) no site preparation with broadcast seeding. Disking killed from 25 to $40 \%$ of the broom snakeweed.

In September 1945 crested wheatgrass and western wheatgrass were growing well. The species on strip plots were flourishing, particularly under the slash and row plantings had emerged. By 1947 the survival was confined primarily to mulch. Turkestan bluestem and little bluestem were prominent. Intermediate and pubescent wheatgrasses, smooth brome, plains and sand lovegrass, and wolftail had established good stands but stands of black and hairy grama, smilograss, and vinemesquite were only fair. Tanglehead was established but it was a poor stand.

In 1949 there was an excellent stand of Turkestan bluestem under the mulch and a good stand without litter. Under mulch the stand of weeping lovegrass was good to excellent; that of white tridens, good; and crested and western wheatgrasses, fair. For row plantings there were good stands of intermediate and pubescent wheatgrasses, plains and sand lovegrasses, with fair stands of crested wheatgrass and vinemesquite.

By 1954, under mulch, stands of Turkestan bluestem, weeping lovegrass, deergrass, and crested and western wheatgrasses were good to excellent. Only Turkestan bluestem was in a good stand without mulch. On some plots good stands of crested and western wheatgrasses became established under mulching, both with and without cultivation. Thus mulching may partially compensate for poor seedbed 
preparation.

In 1961 and 1965 the outstanding species were Turkestan bluestem, weeping lovegrass, and western wheatgrass. Crested wheatgrass was disappearing. Turkestan bluestem was vigorously spreading in 1965. No species was present in 1975.

\section{Management Implications}

After 30 years only six species of grass and one species of shrub remained out of the original plantings. The chaparral planting site was the vegetation type where the most species survived (Figs. 1 and 2). Good stands of Boer and Lehmann lovegrass and menodora are established. Observations indicate that menodora has increased in density from the original planting. Scattered plants of sand dropseed were present and occasional plants of blue panicgrass. White tridens survived until 1970. Over the years these last two species seem to disappear some seasons but make periodic comebacks. Perhaps this was due to moisture relations.

Of the 48 species planted, 13 (Table 1, 1965) appear to be able to survive for at least 20 years. These species should be good candidates for restoring depleted rangelands in the Southwest, the species used depending on the site. Two whe atgrasses, Turkes$\tan$ bluestem, three lovegrasses, and rough menodora did well where planted, particularly with site preparation and mulching.

By sites, species surviving which survived the full 30 years are crested wheatgrass and weeping lovegrass in the grassland, and Boer and Lehmann lovegrasses, blue panicgrass, sand dropseed, and menodora in the chaparral. No species survived in the semidesert shrub and pinyon-juniper sites.

\section{Literature Cited}

Glendening, G. E. 1937a. A method of revegetating small key plots on eroded areas. Southwestern Forest and Range Exp. Sta. Res. Note 8. 2 p.

Glendening, G. E. 1937b. Improving depleted ranges through artificial revegetation. West. Livestock J. 2 p. (November).

Glendening, G. E. 1938. The place of tanglehead in artificial revegetation. Southwestern Forest and Range Exp. Sta. Res. Note 37. 2 p.

Griffiths, D. 1907. The reseeding of depleted range and native pastures. U.S. Dep. Agr. Bur. Plant Ind. Bull. 117. $22 \mathrm{p}$.

Sampson, A. W. 1913. The reseeding of depleted grazing lands to cultivated forage plants. U.S. Dep. Agr. Bull. 4. 34 p. 